\title{
Saw Palmetto (Serenoa repens) Flowering and Fruiting Response to Time Since Fire
}

\author{
Mary E. Carrington ${ }^{1}$ and J. Jeffrey Mullahey ${ }^{2}$ \\ Authors are ${ }^{1}$ Professor, Science Division, Governors State University, University Park, IL 60466, USA; and ${ }^{2}$ Head, Department of Crop Science, North \\ Carolina State University, Raleigh, NC 27695, USA.
}

\begin{abstract}
Saw palmetto (Serenoa repens [Bartr.] Small) is a shrubby palm common in southeastern US pine flatwoods ecosystems. Demand recently has increased for fruits for the herbal remedies market. Because only wild saw palmettos are harvested, management strategies are needed to promote flowering and fruiting. This study investigated effects of time since growing season (April-July) fires on flowering and fruiting of saw palmetto ramets $\geq 54 \mathrm{~cm}$ in height, in 18 pine flatwoods or dry prairie sites (six sites in three locations, burned in 1996, 1995, 1994, 1993, 1992, or before 1991) in central and southwest Florida from 1996 to 1999. We used repeated measures, linear mixed models to test for time since fire effects on proportion of ramets flowering, proportion of ramets fruiting, and fruit yield. Ranges of means among sites over all years of the study for proportion of ramets flowering, proportion of ramets fruiting, and fruit yield were 0 to $0.78,0$ to 0.72 , and $0 \mathrm{~kg} \cdot \mathrm{ha}^{-1}$ to $2869 \mathrm{~kg} \cdot \mathrm{ha}^{-1}$, respectively. Time since fire strongly influenced flowering; highest probability of flowering occurred $1 \mathrm{yr}$ after burning, followed by an abrupt decrease 2 $\mathrm{yr}$ after burning, then a gradual increase from 3 to $5 \mathrm{yr}$ after fires (polynomial regression, $P<0.0001$ for fixed effects). Probability of fruiting increased with increasing time since fire (quadratic regression, $P<0.001$ for fixed effects), but fruit yields showed no pattern in response to time since fire $(P=0.916)$. The decrease in influence of fire from flowering through fruit maturity presumably was caused by mortality from factors such as caterpillar predation and fungal infection. To promote increased flowering and fruit yields, we recommend that growing season burns be conducted approximately every 5 yr. We suggest, however, that management strategy be modified as necessary to maintain ecosystem diversity and function.
\end{abstract}

Key Words: ecosystem management, fire, flatwoods, Florida, forest management, plant ecology

\section{INTRODUCTION}

Saw palmetto (Serenoa repens [Bartr.] Small) is a key species in pine flatwoods and dry prairies, fire-prone natural ecosystems comprising approximately 400000 ha in southwest Florida (Shriver and Vickery 1999; Florida Natural Areas Inventory 2008). Synchronous flowering of this abundant dwarf palm provides resources in the form of nectar, pollen, or fruit for hundreds of invertebrate and vertebrate species (Maehr and Layne 1996; Carrington et al. 2003); and fruits increasingly are harvested for the herbal remedies market in the United States and Europe (American Herbal Products Association 2007). Although studies have shown that saw palmetto generally flowers in response to burning (Abrahamson 1999; Carrington and Mullahey 2006), relatively little is known about how saw palmetto flowering and fruiting patterns change in response to time since fire across a range of sites. This research examines flowering and fruiting patterns in response to time since fire by combining chronosequence and longitudinal study approaches across a range of sites in three locations in southwest and south-central Florida.

Research was funded by Dr. Willmar Schwabe GmbH \& Co., Indena Spa, Laboratoires Pierre Fabre Sante, Plantation Medicinals, Inc, and Wilcox Natural Products, Inc.

At the time of the research, Carrington was a postdoctoral associate, South Florida Research and Education Center, University of Florida, Immokalee, FL 34142, USA.

Correspondence: Mary E. Carrington, Science Division, Governors State University, University Park, IL 60466, USA. Email: mcarrington@govst.edu

Manuscript received 4 October 2011; manuscript accepted 5 August 2012.

(c) 2013 The Society for Range Management
Saw palmetto is native to the Southeastern Coastal Plain of the United States, ranging north to South Carolina and west to Louisiana (Hilmon 1968). Although the species occurs in a wide variety of seasonally flooded to upland ecosystems, it reaches its greatest abundance in pine flatwoods and dry prairie ecosystems in southwest Florida. Here the palmettos form a dense, virtually monospecific understory either with or without a pine overstory in pine flatwoods and dry prairies, respectively (Abrahamson and Hartnett 1990).

The natural fire regime in pine flatwoods and dry prairies is frequent, relatively low intensity growing season fires. Although natural fire frequency probably was variable, more open stands with higher species diversity likely burned every 1 to $3 \mathrm{yr}$ (Christensen 1981; Mitchell et al. 2006). Saw palmetto has functional attributes well suited to the natural fire regime of pine flatwoods and dry prairies; moreover, it may be considered a key species in these ecosystems. Saw palmetto is a clonal, extremely long-lived species that reproduces vegetatively via woody rhizomes lying on or just below the soil surface. Functioning as the main component of the understory, this species provides nesting and denning habitat and shelter for over 100 bird, mammal, reptile, and amphibian species (Maehr and Layne 1996), and it sequesters carbon for hundreds of years in its rhizomes (Gholz et al. 1999; Powell et al. 2005; Saha et al. 2010; Takahashi et al. 2011). Its living and dead fronds are the primary fuel for frequent ground fires. Although these fires typically consume all above-ground foliage in the understory, mortality of adult saw palmettos is virtually nil, and new leaf growth is usually visible within days of burning (Hilmon 1968; Abrahamson 1995). In addition, saw palmettos 
flower synchronously after burning at any time of the year (Abrahamson 1999; Carrington and Mullahey 2006).

In the absence of fire, most saw palmetto flowering occurs from March through May (Hilmon 1968). Saw palmetto flowering events result in a large seasonal pulse of resources for nectar and pollen-consuming insects; several hundred insect taxa have been observed visiting saw palmetto flowers (M. Deyrup, personal communication, March 1997; Carrington et al. 2003). Fruits are drupes, which begin developing in May, and ripen to a dark purple-black color during October through December (Hilmon 1968). Ripe fruits are high in energy, digestible nutrition, and fats (Abrahamson and Abrahamson 1989), and they are an important source of food for many wildlife species (Maehr and Layne 1996).

Beginning during the 18th century and continuing to the present, pine flatwoods and wet prairies have been altered or lost through changes in fire regime or conversion to other land uses. Most existing pine flatwoods and wet prairies in southwest Florida currently are managed 1 ) as rangeland for cattle, 2) for pulpwood or timber harvest, or 3 ) as natural areas on publicly owned land (Abrahamson and Hartnett 1990; Florida Natural Areas Inventory 2008). With the possible exception of publicly owned land, management has resulted in an altered fire regime (i.e., change in fire season and reduced fire frequency) on most of this land. Land managers typically use prescribed burning as a management tool to reduce coverage of woody species, promote new growth of forage, and improve accessibility (Kalmbacher et al. 1983). Most prescribed burns, however, are conducted during the dormant season rather than the growing season, because dormant season fires ignite more readily and are easier to control. Additionally, in some cases decrease in fire frequency through fire exclusion has occurred, resulting in changes in plant species composition, ecosystem structure and nutrient cycling, and reductions in biodiversity (Abrahamson and Hartnett 1990; Mitchell et al. 2006). Pine flatwoods and wet prairies also have been altered or lost through destruction of the saw palmettos themselves. Because saw palmetto produces relatively low-quality forage, range managers historically have considered it an undesirable species and have tried to eradicate it to make way for higher-quality forage species (Tanner et al. 1996; Carrington et al. 2000).

During the 1990s, however, the monetary value of saw palmetto increased, resulting in at least some change in management practices. Demand for saw palmetto fruits increased for use in treatment of benign prostatic hypertrophy $(\mathrm{BPH})$, an enlarged prostate gland condition common in older men (Berry et al. 1984). From 1996 to 2005, annual harvests of saw palmetto fruits in Florida ranged from 3 to 8 million $\mathrm{kg}$, with a monetary value of $\$ 1.65-5$ million (M. Huffman, personal communication, March 1999; American Herbal Products Association 2007). Because saw palmetto grows slowly and is extremely long-lived, it cannot be reliably cultivated, so fruits are wild-harvested from pine flatwoods and dry prairie ecosystems. Consequently, landowners have become interested in the commercial value of saw palmetto, and in management practices to promote flowering and fruiting.

Because saw palmettos commonly flower after burning, and because prescribed burning already is an established, relatively inexpensive management practice for native range, burning may be a practical, effective management tool to promote saw palmetto flowering and fruiting. Relatively little is known, however, about how saw palmetto flowering and fruiting differs in response to time since fire. Results of past studies suggested that 1 ) increased flowering occurs after both growing season and winter burns (Abrahamson 1999; but see Carrington and Mullahey 2006) but fruit set is reduced after winter burns (Abrahamson 1984; Carrington and Mullahey 2006), and 2) frequent burning (i.e., every 2 to $3 \mathrm{yr}$ ) reduces flowering (Hilmon 1968) and fruiting (Carrington and Mullahey 2006).

The objective of this study was to characterize effects of time since fire on saw palmetto flowering and fruiting. We restricted the study to growing season burns, because these burns are likely to produce higher fruit yields due to higher fruit set. We quantified flowering and fruiting of saw palmettos over a period of $3 \mathrm{yr}$ in sites that had burned 1, 2, 3, 4, and $>5 \mathrm{yr}$ previously.

\section{METHODS}

\section{Study Sites}

We quantified saw palmetto flowering and fruiting from August 1996 through August 1999 in 18 pine flatwoods or dry prairie sites in southwest and south-central Florida. In pine flatwoods and dry prairies, sandy soils frequently are underlain by a clay hardpan, and the water table is close to the soil surface. Consequently, these ecosystems may flood during periods of abundant rainfall, or surface soils may become extremely dry during dry periods (Abrahamson and Hartnett 1990).

Climate of the region is subtropical, with an average freeze return interval $>3 \mathrm{yr}$ (Holdridge et al. 1971; Obeysekera et al. 1999). Most plant growth, flowering, and fruiting occurs during April through August, which we define here as the growing season. Mean temperature during the growing season is $26^{\circ} \mathrm{C}$. While approximately $60 \%$ of the $135-\mathrm{cm}$ annual precipitation occurs during the growing season (Southwest Florida Water Management District 2011; University of Florida 2011), fluctuations in precipitation amounts among years potentially can influence fire behavior and Serenoa flowering and fruiting. At Archbold Biological Station, one of our study locations, total precipitation during the growing seasons of 1997, 1998, and 1999 were $94 \mathrm{~cm}, 40 \mathrm{~cm}$, and $120 \mathrm{~cm}$, respectively. Keetch-Byram Drought Index measurements over the same time periods indicated that the growing season of 1997 began much wetter than the growing seasons of 1998 or 1999 (Archbold Biological Station/Archbold Reserve 2012; Fig. $1)$.

Six study sites each were located in three locations: Avon Park Air Force Range (lat $27^{\circ} 34^{\prime} \mathrm{N}$, long $81^{\circ} 18^{\prime} \mathrm{W}$ ), Archbold Biological Station (lat $27^{\circ} 11^{\prime} \mathrm{N}$, long $81^{\circ} 21^{\prime} \mathrm{W}$ ), and Myakka River State Park (lat $27^{\circ} 15^{\prime} \mathrm{N}$, long $82^{\circ} 17^{\prime} \mathrm{W}$; Carrington and Mullahey 2006). Myakka River State Park and Avon Park Air Force Range are in the Southwestern Flatwoods and Eastern Flatwoods physiographic districts, respectively (Weekley et al. 2008). Both physiographic districts are typified by low, flat terrain over Miocene to Pleistocene rocks and sediments (Brown et al. 1990). Soils are typically poorly to very poorly drained flatwoods spodosols (Carrington and Mullahey 2006). Archbold Biological Station is on the Lake Wales Ridge in the Central Lake physiographic district, with gently rolling terrain 
a.
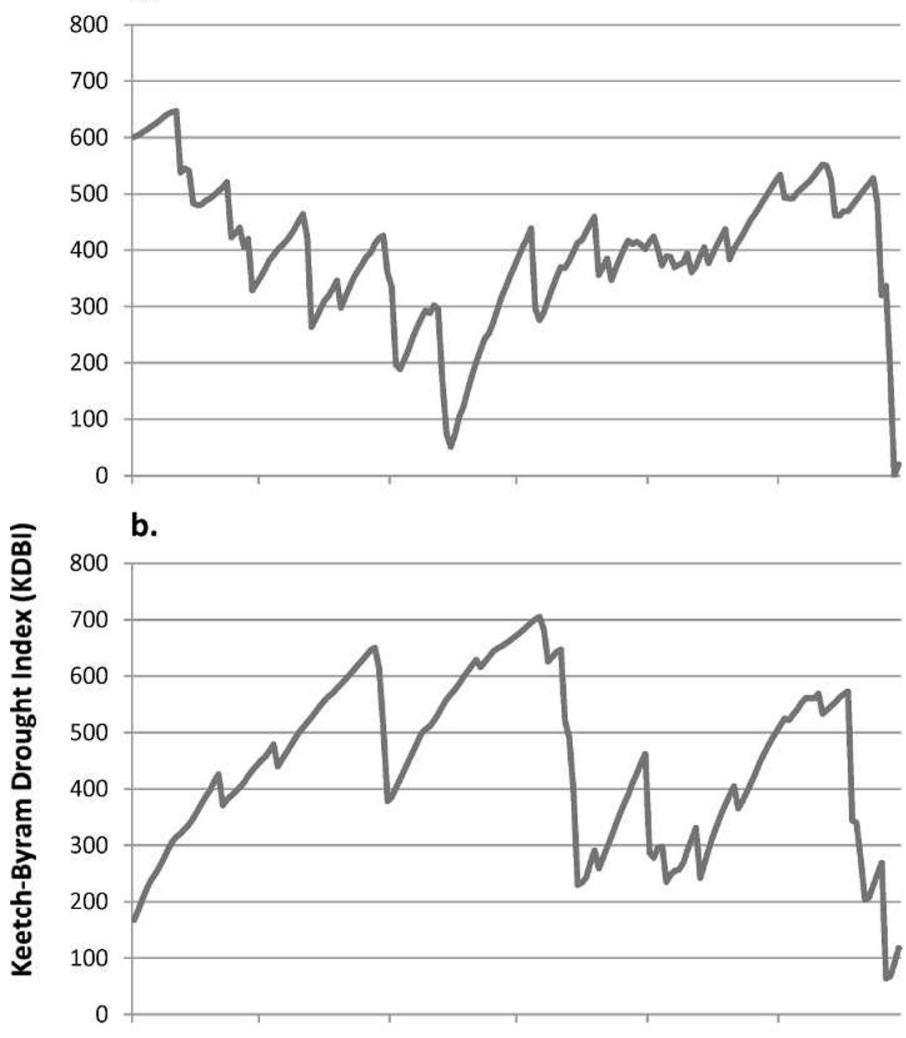

c.

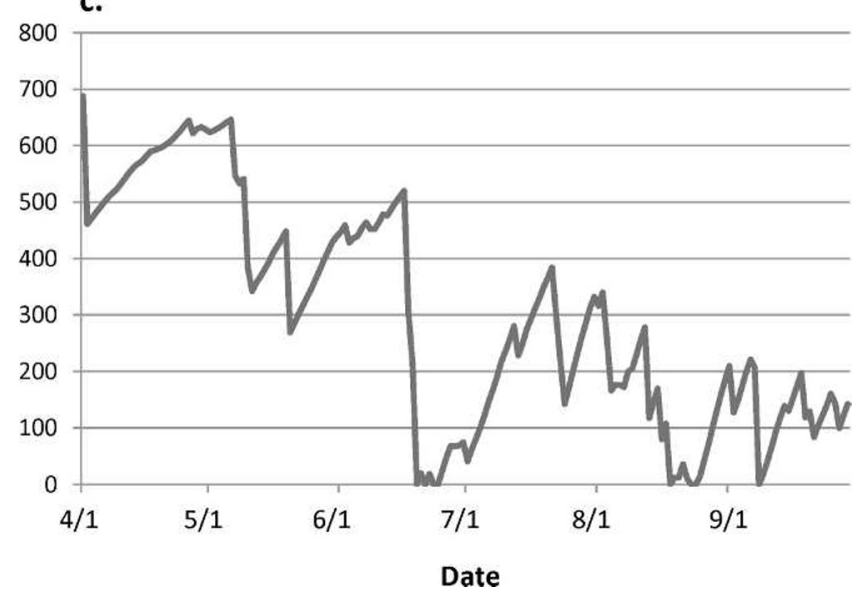

Figure 1. Keetch-Byram Drought Index (KBDI) values calculated from climate data collected at Archbold Biological Station, Florida, during 1 April through 30 September of 1997 (a), 1998 (b), and 1999 (c; Archbold Biological Station/Archbold Reserve 2012).

(Weekley et al. 2008). Soils at study sites in these locations varied from typical flatwoods soils (Myakka and Immokalee soil series) to deeper, more well-drained soils (Satellite and Archbold soil series; US Department of Agriculture 1989; Carrington and Mullahey 2006). Cattle grazing occurred at Avon Park Air Force range sites; nevertheless, grazing had no discernible effect on flowering or fruiting in this study. Grazing did not occur at sites in the other two locations.

Pines in the sites were longleaf pines (Pinus palustris Mill.), south Florida slash pines (Pinus elliottii Engelm. var. densa Little \& Dorman), slash pines (P. elliottii Engelm.), or some combination of the three types. Pine densities in sites ranged from 0 trees $\cdot \mathrm{ha}^{-1}$ to 227 trees $\cdot \mathrm{ha}^{-1}$. Other associated plant species included wax myrtle (Myrica cerifera L.), gallberry (Ilex opaca Aiton), fetterbush (Lyonia lucida [Lam.] K. Koch), staggerbush (Lyonia fruticosa [Michx.] G. S. Torr.), tarflower (Bejaria racemosa Vent.), wiregrass (Aristida stricta Michx. var. beyrichiana [Trin. \& Rupr.] D. B. Ward), little bluestem (Schizachyrium scoparium [Michx.] Nash), lopsided Indiangrass (Sorghastrum secundum [Elliott] Nash), goldenaster (Pityopsis graminifolia [Michx. Nutt.), vanilla plant (Carphephorus odoratissimus [J. F. Gmel.] H. Hebert), and blazing star (Liatris tenuifolia Nutt.).

\section{Field Measurements}

In August 1996 in each of our three locations, we selected six pine flatwoods or dry prairie sites. Each site last burned in 1996, 1995, 1994, 1993, 1992, or before 1991. All sites were burned during the growing season (i.e., April-July). In each site, we positioned and marked 10 permanent, 5-m line transects in a stratified random manner, so that adjacent transects were 5-30 m apart. Direction of each transect was random (excluding directions that would take us outside the site boundaries).

At each line transect at the beginning of the study, we measured the crown height and crown width for each saw palmetto ramet with foliage crossing the transect. For the purposes of this study, we defined a ramet as a crown of leaves (i.e., one meristem) with its accompanying rhizome. We defined crown height as the distance from the petiole bases to the tip of the tallest leaf. We marked all ramets with crown heights $\geq 54$ $\mathrm{cm}$ by attaching an aluminum tag to a leaf petiole; all subsequent measurements were made on ramets of this size. We defined $54 \mathrm{~cm}$ as a minimum height for saw palmetto flowering based on data collection on 250 ramets in a previous study, in which no ramets $<54 \mathrm{~cm}$ flowered. We estimated density of saw palmetto ramets in each site by counting ramets in ten $2 \times 5 \mathrm{~m}$ quadrats in each site. We positioned the quadrats in each site in a stratified random manner, in the same way that we positioned line transects.

During April 1997, 1998, and 1999 (April was determined as the month of peak flowering from unpublished phenological data from 250 ramets), we estimated proportion of saw palmettos flowering for each site. We counted the number of marked ramets that were flowering, calculated proportion of ramets flowering for each transect, and averaged proportions flowering over the 10 transects for each site. During August 1996, 1997, 1998, and 1999 (unpublished phenological data showed August as the month of peak fruiting), we estimated proportion of saw palmettos fruiting, and fruit yield for each site. At each transect, we counted the number of marked ramets that were fruiting, and picked and weighed fruits from each fruiting ramet. We calculated mean proportion of ramets fruiting for each site in the same way that we calculated mean proportion flowering. To calculate estimated fruit yield for each site, we multiplied mean proportion fruiting by mean ramet density (averaged over 10 quadrats) and mean fruit weight per ramet (averaged over all fruiting ramets).

\section{Data Analysis}

At the individual ramet level, we determined the relationship of probability of flowering during the $3 \mathrm{yr}$ of the study (response 
Table 1. Mean proportions of saw palmetto (Serenoa repens) ramets flowering during April 1997, 1998, and 1999 at Archbold Biological Station, Avon Park Air Force Range, and Myakka River State Park in central and southwest Florida.

\begin{tabular}{ccccc}
\hline & & \multicolumn{3}{c}{$\begin{array}{c}\text { Proportion ramets flowering } \\
\text { (mean } \pm \mathrm{SD}, n=10 \text { transects) }\end{array}$} \\
\cline { 3 - 5 } Site & Year last burned & 1997 & 1998 & 1999 \\
\hline Archbold & 1996 & $0.61 \pm 0.28$ & $0.05 \pm 0.09$ & $0.21 \pm 0.18$ \\
Archbold & 1995 & $0.04 \pm 0.07$ & $0.24 \pm 0.29$ & $0.32 \pm 0.29$ \\
Archbold & 1994 & $0.08 \pm 0.11$ & $0.12 \pm 0.15$ & $0.45 \pm 0.20$ \\
Archbold & 1993 & $0.22 \pm 0.26$ & $0.26 \pm 0.22$ & $0.38 \pm 0.20$ \\
Archbold & 1992 & $0.22 \pm 0.17$ & $0.39 \pm 0.24$ & $0.15 \pm 0.22$ \\
Archbold & pre 1991 & $0.19 \pm 0.20$ & $0.44 \pm 0.22$ & $0.31 \pm 0.25$ \\
Avon Park & 1996 & $0.26 \pm 0.35$ & $0.02 \pm 0.05$ & $0.35 \pm 0.37$ \\
Avon Park & 1995 & $0.00 \pm 0.00$ & $0.13 \pm 0.15$ & $0.30 \pm 0.23$ \\
Avon Park & 1994 & $0.63 \pm 0.31$ & $0.15 \pm 0.31$ & $0.16 \pm 0.15$ \\
Avon Park & 1993 & $0.03 \pm 0.07$ & $0.06 \pm 0.13$ & $0.20 \pm 0.34$ \\
Avon Park & 1992 & $0.22 \pm 0.23$ & $0.45 \pm 0.33$ & $0.45 \pm 0.29$ \\
Avon Park & pre 1991 & $0.52 \pm 0.37$ & $0.53 \pm 0.36$ & $0.47 \pm 0.31$ \\
Myakka & 1996 & $0.50 \pm 0.34$ & $0.17 \pm 0.18$ & $0.52 \pm 0.36$ \\
Myakka & 1995 & $0.42 \pm 0.23$ & $0.23 \pm 0.22$ & $0.23 \pm 0.20$ \\
Myakka & 1994 & $0.24 \pm 0.20$ & $0.23 \pm 0.11$ & $0.20 \pm 0.17$ \\
Myakka & 1993 & $0.07 \pm 0.06$ & $0.17 \pm 0.11$ & $0.23 \pm 0.25$ \\
Myakka & 1992 & $0.11 \pm 0.12$ & $0.33 \pm 0.22$ & $0.55 \pm 0.20$ \\
Myakka & pre 1991 & $0.31 \pm 0.18$ & $0.49 \pm 0.27$ & $0.78 \pm 0.25$ \\
\hline
\end{tabular}

variables were dichotomous flowering $=1$ or nonflowering $=0$ for 1997, 1998, and 1999) to variables estimating ramet size (predictor variables were crown width and crown height). We used generalized estimating equations (GEEs) within the Genmod procedure in SAS (SAS Institute, Inc, Cary, NC), which allow analysis of nonlinear, likely correlated response variables (Liang and Zeger 1986). By using a logit link function within the Genmod procedure, we fit a linear model to the flowering outcome data using a parsimonious independent correlation structure (Pan and Connett 2002). We conducted this analysis using data for ramets $\geq 54 \mathrm{~cm}$ in height in all sites.

At the site level, we used separate linear mixed models with repeated measures to test for time since fire effects on mean proportion of ramets flowering, mean proportion of ramets fruiting, and estimated fruit yield, respectively. Values for mean proportion of ramets flowering and mean proportion of ramets fruiting were arcsine-transformed before analysis. Time since fire was treated as a fixed effect, mean crown width was included as a covariate, and individual sites were the repeated subjects. We determined the best covariance structure for each analysis by comparing the fit of three commonly used covariance structures (autoregressive order 1, unstructured and unstructured allowing variance parameters to vary by location) to the ordinary least-squares model using the null likelihood ratio test, and by comparing fits among the three covariance structures using the Akaike information criterion (Littell et al. 1996).

For the analyses conducted on proportion of ramets fruiting and fruit yield data, we omitted data collected in 1996 from sites burned in 1996, because saw palmettos in sites burned during the growing season typically do not flower or fruit until
Table 2. Estimates and precision of estimates of fixed effects, and Student's $t$ tests of fixed effects for fourth power polynomial model of arcsine-transformed mean probability of saw palmetto (Serenoa repens) flowering in response to time since fire (tsf).

\begin{tabular}{lrccrc}
\hline Effect & Estimate & Standard error & df & \multicolumn{1}{c}{$t$} & $P$ \\
\hline Intercept & 2.96 & 0.20 & 17 & 14.7 & $<0.0001$ \\
tsf & -3.25 & 0.24 & 32 & -13.8 & $<0.0001$ \\
tsf $^{2}$ & 1.37 & 0.11 & 32 & 12.6 & $<0.0001$ \\
tsf $^{3}$ & -0.24 & 0.02 & 32 & -11.0 & $<0.0001$ \\
tsf $^{4}$ & 0.01 & 0.00 & 32 & 9.7 & $<0.0001$ \\
\hline
\end{tabular}

the year following burning (Abrahamson 1984; Abrahamson 1999; Carrington and Mullahey 2006). In addition, due to a fruiting failure in 1997 caused by anthracnose (Colletotrichum gloeosporioides Penz.), we omitted 1997 data from the analyses. Consequently, the analyses of proportion of ramets fruiting and fruit yield included data from 1996, 1998, and 1999.

\section{RESULTS}

A total of 940 ramets $\geq 54 \mathrm{~cm}$ in height were marked and repeatedly sampled during the study, with crown widths and crown heights $78.0 \pm 27$ and $82.2 \pm 19 \mathrm{~cm}$ (mean $\pm \mathrm{SD}$ ), respectively. Myakka sites (in Southwestern Flatwoods physiographic district) had higher ramet densities than Archbold (in Central Lake physiographic district) or Avon Park sites (in Eastern Flatwoods physiographic district). Mean ramet densities in Myakka sites ranged from 21000 ramets $\cdot \mathrm{ha}^{-1}$ to 34500 ramets $\cdot \mathrm{ha}^{-1}$, and mean densities in Archbold and Avon Park sites ranged from 10900 ramets $\cdot \mathrm{ha}^{-1}$ to 20100 ramets $\cdot \mathrm{ha}^{-1}$.

Of the 940 ramets, $44 \%$ never flowered during the study, $37 \%$ flowered during 1 of the $3 \mathrm{yr}, 16 \%$ flowered during 2 of the $3 \mathrm{yr}$, and $3 \%$ flowered during all $3 \mathrm{yr}$ of the study. GEEs indicated that crown width $(P<0.001)$, but not crown height $(P=0.2947)$, was a good predictor of flowering. The odds of a ramet flowering increased $1 \%$ for each centimeter increase in crown width (odds ratio $=1.009,95 \%$ confidence inter$\mathrm{val}=1.006-1.013)$.

At the site level, mean values for proportion of ramets flowering in 1997, 1998, and 1999 ranged from 0 to 0.78 , with the highest mean proportion flowering occurring in a site burned more than $5 \mathrm{yr}$ before sampling. Of the 54 mean values (values for 18 sites sampled over $3 \mathrm{yr}$ ), eight means were $<0.10$, and eight means were $\geq 0.50$ (Table 1 ). The best fit regression model for arcsine-transformed proportion of ramets flowering was a polynomial function to the fourth power of time since fire, with an unstructured covariance structure allowing variance parameters to vary by location. Crown width as a covariate was not a source of variation $(P=0.246)$, so was left out of the best fit model (Table 2$)$. The polynomial regression model predicted the highest probability of flowering $1 \mathrm{yr}$ after burning, followed by an abrupt decrease $2 \mathrm{yr}$ after burning. Following the second year after burning, the model predicted a relatively gradual increase in probability of flowering; however, sites exhibited high variability around this trend (Fig. 2). 


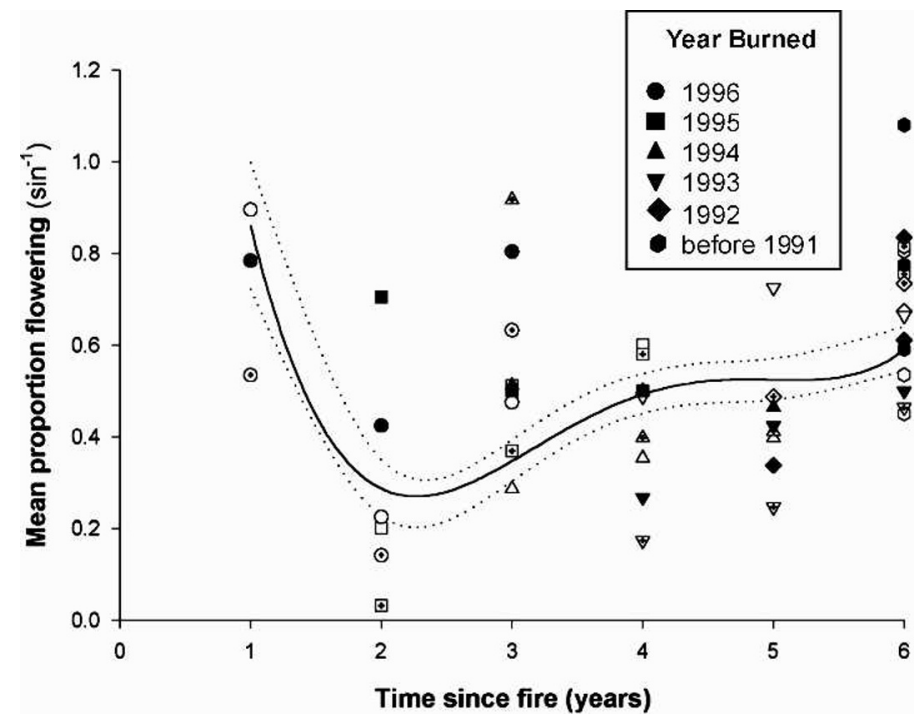

Figure 2. Arcsine-transformed mean proportions of saw palmetto (Serenoa repens) ramets flowering at $1,2,3,4,5$, and $>5 \mathrm{yr}$ since growing season fires in 18 pine flatwoods or dry prairie sites at Archbold Biological Station (open symbols), Avon Park Air Force Range (open symbols with plus sign), and Myakka River State Park (filled symbols) in central and southwest Florida. Lines represent a fourth order polynomial regression and upper and lower confidence limits.

Mean values for proportion of ramets fruiting in 1996, 1998, and 1999 ranged from 0 to 0.72 , with the highest mean proportion fruiting occurring in a site $1 \mathrm{yr}$ after burning. In 17 of 18 sites sampled in 1998 and in 16 of 17 sites sampled in

Table 3. Mean proportions of saw palmetto (Serenoa repens) ramets fruiting during August 1996, 1998, and 1999 at Archbold Biological Station, Avon Park Air Force Range, and Myakka River State Park in central and southwest Florida.

\begin{tabular}{ccccc}
\hline & & \multicolumn{3}{c}{$\begin{array}{c}\text { Proportion ramets fruiting } \\
\text { (mean } \pm \text { SD, } n=10 \text { transects) }\end{array}$} \\
\cline { 3 - 5 } Site & Year last burned & 1996 & 1998 & 1999 \\
\hline Archbold & 1996 & -1 & $0.03 \pm 0.08$ & $0.07 \pm 0.10$ \\
Archbold & 1995 & $0.72 \pm 0.27$ & $0.13 \pm 0.14$ & $0.34 \pm 0.30$ \\
Archbold & 1994 & $0.09 \pm 0.11$ & $0.08 \pm 0.12$ & $0.08 \pm 0.08$ \\
Archbold & 1993 & $0.43 \pm 0.16$ & $0.32 \pm 0.17$ & $0.19 \pm 0.24$ \\
Archbold & 1992 & $0.49 \pm 0.32$ & $0.30 \pm 0.23$ & - \\
Archbold & pre 1991 & $0.17 \pm 0.14$ & $0.18 \pm 0.21$ & $0.19 \pm 0.21$ \\
Avon Park & 1996 & - & $0.00 \pm 0.00$ & $0.18 \pm 0.28$ \\
Avon Park & 1995 & $0.12 \pm 0.21$ & $0.00 \pm 0.00$ & $0.25 \pm 0.19$ \\
Avon Park & 1994 & $0.05 \pm 0.11$ & $0.08 \pm 0.11$ & $0.14 \pm 0.15$ \\
Avon Park & 1993 & $0.02 \pm 0.06$ & $0.04 \pm 0.08$ & $0.00 \pm 0.00$ \\
Avon Park & 1992 & $0.10 \pm 0.12$ & $0.19 \pm 0.22$ & $0.24 \pm 0.21$ \\
Avon Park & pre 1991 & $0.00 \pm 0.00$ & $0.49 \pm 0.37$ & $0.33 \pm 0.36$ \\
Myakka & 1996 & - & $0.02 \pm 0.04$ & $0.20 \pm 0.19$ \\
Myakka & 1995 & $0.06 \pm 0.16$ & $0.00 \pm 0.00$ & $0.00 \pm 0.00$ \\
Myakka & 1994 & $0.01 \pm 0.03$ & $0.11 \pm 0.15$ & $0.12 \pm 0.16$ \\
Myakka & 1993 & $0.10 \pm 0.14$ & $0.10 \pm 0.11$ & $0.10 \pm 0.15$ \\
Myakka & 1992 & $0.19 \pm 0.12$ & $0.17 \pm 0.15$ & $0.27 \pm 0.13$ \\
Myakka & pre 1991 & $0.08 \pm 0.13$ & $0.22 \pm 0.15$ & $0.55 \pm 0.24$ \\
\hline My & & &
\end{tabular}

1-, data not collected due to a fungus-caused fruiting failure at all sites.
Table 4. Estimates and precision of estimates of fixed effects, and Student's $t$ tests of fixed effects for quadratic model of arcsine-transformed mean probability of saw palmetto (Serenoa repens) fruiting in response to time since fire (tsf).

\begin{tabular}{lcccrr}
\hline Effect & Estimate & Standard error & df & \multicolumn{1}{c}{$t$} & \multicolumn{1}{c}{$P$} \\
\hline Intercept & -0.27 & 0.06 & 17 & -4.5 & 0.0003 \\
tsf & 0.22 & 0.34 & 30 & 6.4 & $<0.0001$ \\
tsf $^{2}$ & -0.02 & 0.00 & 30 & -4.1 & 0.0003 \\
\hline
\end{tabular}

1999, mean proportion fruiting was less than mean proportion flowering earlier in the same year (Tables 1 and 3). For arcsinetransformed proportion of ramets fruiting, the best fit regression model was a quadratic function of time since fire with an unstructured covariance structure allowing variance parameters to vary by location. Crown width as a covariate was not a source of variation $(P=0.760)$, so it was left out of the best fit model (Table 4). The regression model predicted that probability of fruiting increases gradually with increasing time since fire (Fig. 3).

Fruit yield in 1996, 1998, and 1999 ranged from $0 \mathrm{~kg} \cdot \mathrm{ha}^{-1}$ to $2869 \mathrm{~kg} \cdot \mathrm{ha}^{-1}$ (Fig. 4). Fruit yield data were modeled with an unstructured covariance structure with homogeneous variance parameters across locations. Although the highest mean fruit yield occurred $1 \mathrm{yr}$ after burning, neither time since fire $(P=0.916)$ nor crown width as a covariate $(P=0.323)$ explained variation in the data.

\section{DISCUSSION}

This study showed that although time since fire strongly influenced saw palmetto flowering, it did not affect saw palmetto fruiting. The time since fire signature in proportion of ramets flowering - that of a marked peak and trough during the first and second post-fire years followed by a gradual increase-is similar to flowering responses to fire of saw palmettos in other studies (Hilmon 1968; Abrahamson 1999), and of other plant species in fire prone ecosystems (Le Maitre and Brown 1992; Johnson et al. 1994; Brewer 1995; Kirkman et al. 1998; Abrahamson 1999; McConnell and Menges 2002; Verboom et al. 2002). Data from this study also indicate that saw palmetto flowering levels had reached an asymptote, thereby "recovering" from burning, by $5 \mathrm{yr}$ after a fire.

The strong relationship between time since fire and flowering weakened as flowering progressed through seed set to fruit yield. This weak relationship between flowering and fruiting has been shown in other studies (Gholz et al. 1999; Carrington and Mullahey 2006), and presumably resulted from influences other than fire operating at several spatial scales. Evidence of factors influencing fruiting patterns at a regional scale was the 1997 fruiting failure that resulted in virtually no fruit yield, with only one site having any fruit at all. The direct cause of the fruiting failure was premature fruit drop due to infection by the fungus C. gloeosporioides. A regional weather event-heavy rain occurring throughout central and south Florida during April and May 1997-created prime conditions for the fungal infestation (Carrington et al. 2001). 


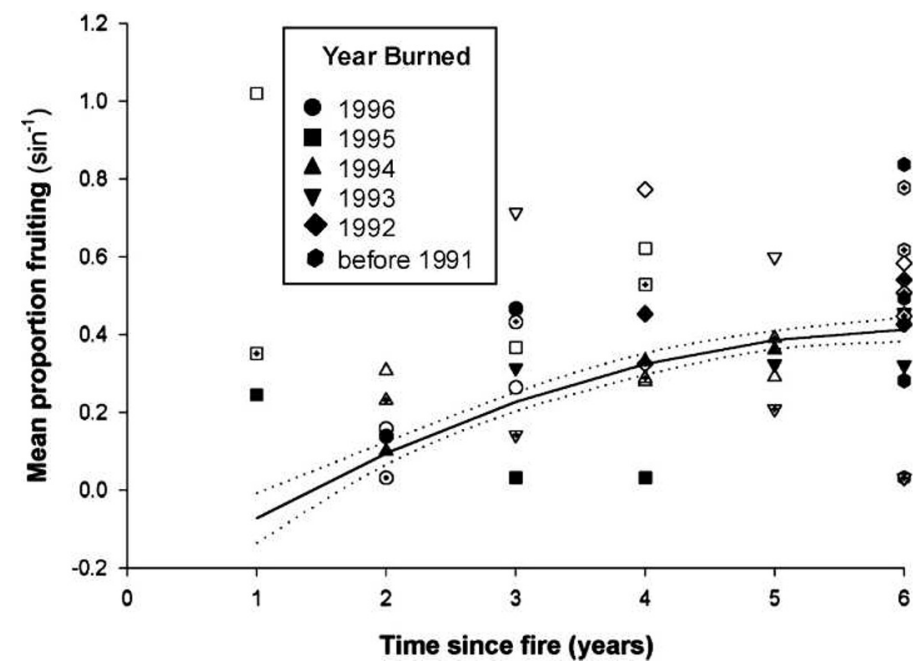

Figure 3. Arcsine-transformed mean proportions of saw palmetto (Serenoa repens) ramets fruiting at $1,2,3,4,5$, and $>5 \mathrm{yr}$ since growing season fires in pine flatwoods or dry prairie sites in central and southwest Florida. Fifteen sites were sampled at Archbold Biological Station (open symbols), Avon Park Air Force Range (open symbols with plus sign), and Myakka River State Park (filled symbols) during August 1996. Eighteen sites (the original 15 plus one additional site burned in 1996 in each of the three locations) were sampled during August in 1998 and 1999. Lines represent a quadratic regression and upper and lower confidence limits.

The most severe reductions in fruit yield from fruiting failures such as this one are likely to occur in sites $1 \mathrm{yr}$ after burning, because these sites have the highest potential fruit yields. Moreover, this fruiting failure likely affected the results of our analyses of mean proportions of ramets fruiting in sites and of mean fruit yields at sites. Our decision to exclude 1997 data from the analyses reduced model estimation power at every value of time since fire, but the most severe power reduction occurred at $1 \mathrm{yr}$ since fire, where only three data points were left for the analyses. Even though all three mean proportion fruiting values were relatively high at $1 \mathrm{yr}$ since fire, the best fit model did not predict high proportions of ramets fruiting $1 \mathrm{yr}$ after burning as the model did for proportion of ramets flowering. It is, therefore, uncertain how much of this model is an artifact of reduced sample size.

Factors at the scale of the location also influenced fruiting as well as flowering patterns, as suggested by the best fit unstructured covariance structures allowing variance parameters to vary by location. Mean proportion of ramets fruiting, however, differed among locations in a different manner than did mean proportion of ramets flowering. Whereas relatively high levels of flowering occurred at least occasionally in sites from all three locations, by the time of fruit set most sites had moderate to low mean proportions of ramets fruiting. Archbold sites (in Central Lake physiographic district, with relatively well drained soils), with higher mean proportions of ramets fruiting, were an exception to this pattern. Most of the high Archbold values for both proportion of ramets fruiting and fruit yield, however, occurred in 1996, suggesting that some combination of location and year factors resulted in high fruiting levels.

Because we did not collect flowering data until 1997, flowering levels in the Archbold sites during spring of 1996

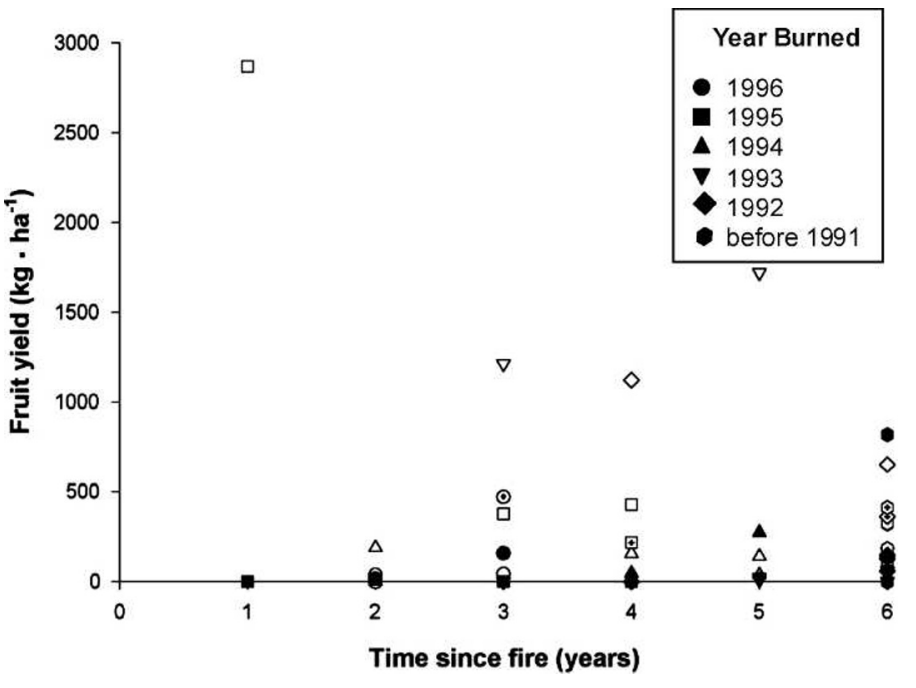

Figure 4. Estimated saw palmetto (Serenoa repens) fruit yield $\left(\mathrm{kg} \cdot \mathrm{ha}^{-1}\right)$ at $1,2,3,4,5$, and $>5 \mathrm{yr}$ since growing season fires in pine flatwoods or dry prairie sites in central and southwest Florida. Fifteen sites were sampled at Archbold Biological Station (open symbols), Avon Park Air Force Range (open symbols with plus sign), and Myakka River State Park (filled symbols) during August 1996. Eighteen sites (the original 15 plus one additional site burned in 1996 in each of the three locations) were sampled during August in 1998 and 1999.

are unknown. Supplemental data collected at some of our study sites during 1998 and 1999, however, showed that the main causes of flower and fruit mortality are the cabbage palm caterpillar (Litoprosopus futilis Grote \& Robinson) and C. gloeosporioides. Litoprosopus, which lives inside bracts that sheathe young inflorescences and eats flower buds, flowers, and sometimes entire inflorescences (Dekle 2010), caused mortality of less than $20 \%$ of inflorescences in 1998 and 1999. And although Colletotrichum caused the fruiting failure in 1997, it is present at some level in sites every year; during 1998 and 1999 it caused mortality of up to $25 \%$ of inflorescences.

Although at the scale of a single ramet we found that increased ramet width was associated with higher probability of flowering, this relationship did not "scale up" to the whole site level, because mean ramet width per site was never a covariate in any of our analyses. This lack of relationship likely is due to the slight potential increase in probability of flowering (and later, probability of fruiting and fruit yield) being overshadowed by other factors discussed earlier that decrease fruiting levels.

\section{IMPLICATIONS}

Three major conclusions relevant to management can be drawn from this study: 1) highest flowering levels occur $1 \mathrm{yr}$ after growing season fires, 2) flowering levels recover by $5 \mathrm{yr}$ following burning, and 3) fruit yields can be extremely variable at any time following fire. To encourage periodic high flowering levels, we recommend growing season prescribed fires on an approximate 5 -yr burning cycle. As this study showed, however, high flowering levels will not guarantee high fruit yields. In general, fruit yields should be 
higher during growing seasons with relatively low rainfall, during which loss of fruits from Colletotrichum should be low. Because Serenoa flowering and fruiting occurs a year after growing season burns, and because predicting weather patterns a year into the future is difficult, managing in a predictable manner for higher fruit yields will continue to be challenging. Dividing large sites into smaller management units that are burned on 5-yr cycles beginning in different years should spread the risk of fruiting failures due to vagaries in weather. In addition, planning burns during interannual dry cycles, such as during a La Niña period (Brolley et al. 2007), may result in higher fruit yields.

Many land managers must balance managing for high fruit yields with maintaining high plant and animal diversity in flatwoods ecosystems, which usually entails frequent burning (i.e., every 2 to $3 \mathrm{yr}$ ). Burning at this higher frequency should keep the height of saw palmetto foliage relatively low, while resulting in lower potential fruit yields. We suggest that management through prescribed burning for this wild-harvested key species be as compatible as possible with other ecosystem functions and services.

\section{ACKNOWLEDGMENTS}

We would like to thank Jim Durrwachter, Sonja Durrwachter, Robert Dye, Jim Snyder, Sam Van Hook, and Carl Weekley for their help in selecting sites and completion of the study. Appreciation goes to Troy Gottfried, Jeff Jones, and Ana Ramirez for assistance with field work and data analysis, and to Steve Coates for assistance with analysis and graphics.

\section{LITERATURE CITED}

Abrahamson, W. G. 1984. Species responses to fire on the Florida Lake Wales Ridge. American Journal of Botany 71:35-43.

Abrahamson, W. G. 1995. Habitat distribution and competitive neighborhoods of two Florida palmettos. Bulletin of the Torrey Botanical Club 122:1-14.

Abrahamson, W. G. 1999. Episodic reproduction in two fire-prone palms, Serenoa repens and Sabal etonia (Palmae). Ecology 80:100-115.

Abrahamson, W. G., and C. R. Abrahamson. 1989. Nutritional quality of animal dispersed fruits in Florida sandridge habitats. Bulletin of the Torrey Botanical Club 116:215-228.

Abrahamson, W. G., and D. C. Hartnett. 1990. Pine flatwoods and dry prairie. In: R. L. Myers and J. J. Ewel [EDS.]. Ecosystems of Florida. Orlando, FL, USA: University of Central Florida Press. p. 103-149.

American Herbal Products Association. 2007. Tonnage survey of select North American wild-harvested plants, 2004-2005. Silver Spring, MD, USA: American Herbal Products Association. $32 \mathrm{p}$.

Archbold Biological Station/Archbold Reserve. 2012. Archbold data and metadata. Available at: http://www.archbold-station.org/station/html/datapub/data/data. Accessed 9 May 2012.

Berry, S. J., D. S. Coffey, P. C. Walsh, and L. L. Ewing. 1984. The development of human benign prostatic hyperplasia with age. Journal of Urology 132:474-479.

BrEWER, J. S. 1995. The relationship between soil fertility and fire-stimulated floral induction in two populations of grassleaved golden aster, Pityopsis graminifolia. Oikos 74:45-54.

Brolley, J. M., J. J. O'Brien, J. Schoo, and D. Zie. 2007. Experimental drought threat forecast for Florida. Agricultural and Forest Meteorology 145:84-96.

Brown, R. B., E. L. Stone, and V. W. Carlisle. 1990. Soils. In: R. L. Myers and J. J. Ewel [EDS.]. Ecosystems of Florida. Orlando, FL, USA: University of Central Florida Press. p. 35-69.

Carrington, M. E., T. D. Gottfried, and J. J. Mullahey. 2003. Pollination biology of saw palmetto (Serenoa repens) in southwestern Florida. Palms 47:95-103.
Carrington, M. E., and J. J. Mullahey. 2006. Effects of burning season and frequency on saw palmetto (Serenoa repens) flowering and fruiting. Forest Ecology and Management 230:69-78.

Carrington, M. E., J. J. Mullahey, G. Krewer, and B. Boland. 2000. Saw palmetto (Serenoa repens): an emerging forest resource in the southeastern United States. Southern Journal of Applied Forestry 24:129-134.

Carrington, M. E., P. D. Roberts, N. V. R. R. Urs, R. J. McGovern, T. E. Seijo, and J. J. MullaheY. 2001. Premature fruit drop in saw palmettos caused by Colletotrichum gloeosporioides. Plant Disease 85:122-125.

Christensen, N. L. 1981. Fire regimes in southeastern ecosystems. In: H. A. Mooney, T. Bonnicksen, N. L. Christensen, W. A. Reiners, and J. Lotan [EDS.]. Fire regimes and ecosystem properties. Washington, DC, USA: US Forest Service. General Technical Report W0-26. p. 112-136.

DekLE, G. W. 2010. Cabbage palm caterpillar, Litoprosopus futilis (Grote \& and Robinson) (Insecta: Lepidoptera: Noctuidae: Ophiderinae). Gainesville, FL, USA: IFAS. Circular EENY-095. $4 \mathrm{p}$.

Florida Natural Areas Inventory. 2008. Florida forever benchmarks, fall 2008, a progress report prepared for the Florida Department of Environmental Protection. Available at: http://www.fnai.org/PDF/FF_Benchmarks_Fall2008.pdf. Accessed 20 September 2011.

Gholz, H. L., D. N. Guerin, and W. P. Cropper. 1999. Phenology and productivity of saw palmetto (Serenoa repens) in a north Florida slash pine plantation. Canadian Journal of Forest Research 29:1248-1253.

Hiımon, J. B. 1968. Autecology of saw-palmetto (Serenoa repens [Bartr.] Small) [dissertation]. Raleigh, NC, USA: Duke University. $175 \mathrm{p}$.

Holdridge, L. R., W. C. Grenke, W. H. Hatheway, T. Liang, and J. A. Tosi, JR. 1971. Forest environments in tropical life zones: a pilot study. Oxford, UK: Pergamon Press. $807 \mathrm{p}$.

Johnson, K. A., D. A. Morrison, and G. Goldsack. 1994. Post-fire flowering patterns in Blandfordia nobilis (Liliaceae). Australian Journal of Botany 42:49-60.

Kalmbacher, R. S., K. J. Boote, And F. G. Martin. 1983. Burning and 2,4,5-T application on mortality and carbohydrate reserves in saw palmetto. Journal of Range Management 36:9-12.

KIRKMan, L. K., M. B. Drew, and D. Edwards. 1998. Effects of experimental fire regimes on the population dynamics of shape Schwalbea americana L. Plant Ecology 137:115-137.

Le Maitre, D. C., and P. J. Brown. 1992. Life cycles and fire-stimulated flowering in geophytes. In: B. W. van Wilgen, D. M. Richardson, F. J. Kruger, and H. J. van Hensbergen [EDS.]. Fire in South African mountain fynbos. Berlin, Germany: Springer-Verlag. p. 145-160.

LIANG, K. Y., AND S. L. ZEGER. 1986. Longitudinal data analysis using generalized linear models. Biometrika 73:13-22.

Littell, R. C., G. A. Milıiken, W. W. Stroup, and R. D. Wolfinger. 1996. SAS system for mixed models. Cary, NC, USA: SAS Institute, Inc. 633 p.

Maehr, D. S., and J. N. Layne. 1996. Florida's all-purpose plant the saw palmetto. Palmetto (Fall):6-10, 15, 21.

McConnelL, K., and E. S. Menges. 2002. Effects of fire and treatments that mimic fire on the Florida endemic scrub buckwheat (Eriogonum Iongifolium Nutt. var. gnaphalifolium Gand.). Natural Areas Journal 22:194-201.

Mitchell, R. J., J. K. Hiers, J. J. O'Brien, S. B. Jack, and R. T. Engstrom. 2006. Silviculture that sustains: the nexus between silviculture, frequent prescribed fire, and conservation of biodiversity in longleaf pine forests of the southeastern United States. Canadian Journal of Forest Research 36:2724-2736.

Obeysekera, J., J. Browder, L. Hornung, and M. A. Harwell. 1999. The natural South Florida system I: climate, geology, and hydrology. Urban Ecosystems 3:223244.

Pan, W., and J. E. Connett. 2002. Selecting the working correlation structure in generalized estimating equations with application to the lung health study. Statistica Sinica 12:475-490.

Powell, T. L., G. Starr, K. L. Clark, T. A. Martin, and H. L. Gholz. 2005. Ecosystem and understory water and energy exchange for a mature, naturally regenerated pine flatwoods forest in north Florida. Canadian Journal of Forest Research 35:1568-1580.

Saha, S., A. Catenazzl, and E. S. Menges. 2010. Does time since fire explain plant biomass allocation in the Florida, USA, scrub ecosystem? Fire Ecology 6:13-25. 
Shriver, W. G., AND P. D. Vickery. 1999. Aerial assessment of potential Florida grasshopper sparrow habitat: conservation in a fragmented landscape. Florida Field Naturalist 27:1-9.

Southwest Florida Water Management District. 2011. Consolidated annual report. Brooksville, FL, USA: South Florida Water Management District. $281 \mathrm{p}$.

Takahashi, M. K., L. M. Horner, T. Kubota, N. A. Keller, and W. G. Abrahamson. 2011. Extensive clonal spread and extreme longevity in saw palmetto, a foundation clonal plant. Molecular Ecology 20:3730-3742.

TanneR, G., J. J. Mullahey, and D. Maehr. 1996. Saw-palmetto: an ecologically and economically important native palm. Gainesville, FL, USA: IFAS. Circular WEC109. $3 \mathrm{p}$.
UNIVERSITY OF FLORIDA. 2011. Florida automated weather network. Available at: http:// fawn.ifas.ufl.edu/data/reports/. Accessed 15 September 2011.

USDA-SCS. 1989. Soil survey of Highlands County, Florida. Washington, DC, USA: USDA-SCS. Available at: http://ufdc.ufl.edu/UF00026062/00001. Accessed 30 March 2012.

Verboom, G. A., W. D. Stock, And H. P. Linder. 2002. Determinants of postfire flowering in the geophytic grass Ehrharta capensis. Functional Ecology 16:705-713.

Weekley, C. W., E. S. Menges, and R. L. Pickett. 2008. An ecological map of Florida's Lake Wales ridge: a new boundary delineation and an assessment of postColumbian habitat loss. Florida Scientist 71:45-64. 